\title{
PEMIKIRAN PENDIDIKAN IBNU JAMA'AH DAN RELEVANSINYA TERHADAP PENDIDIKAN KONTEMPORER
}

\author{
Muhamad Khoirur Roziqin \\ Dosen Program Studi Pendidikan Agama Islam, FAI Universitas KH. A. Wahab \\ Hasbullah \\ indra@unwaha.ac.id \\ Ella Nurmawati \\ Guru MAU Darul Ulum Peterongan Jombang \\ nurmawatiella@gmail.com
}

\begin{abstract}
Abstrak
Pendidikan merupakan sesuatu yang universal dan berlangsung terus menerus tak terputus dari generasi ke generasi dimanapun di dunia ini. Skripsi ini adalah hasil dari studi kepustakaan tentang pemikiran Ibnu Jama'ah dan relevansinya terhadap pendidikan kontemporer. Penelitian ini adalah hasil penelitian kepustakaan (library research) Peneliti menggunakan metode deskriptif analisis yang ditunjang oleh datadata yang diperoleh melalui penelitian kepustakaan (library research), yakni menelusuri literatur serta menelaah untuk menjawab pertanyaan: bagaimana pemikiran pendidikan Ibnu Jama'ah dan relevansinya terhadap pendidikan kontemporer?. Hasil penelitian yang dilakukan oleh peneliti menunjukkan bahwa, Ibnu Jama'ah adalah ilmuwan ensiklopedis, meskipun perhatiannya terfokus pada ilmu agama. Karya beliau mengenai adab atau etika Tazkirah al-Sami' wa alMutakallim fi adab al-Alim wa al-Muta'allim, di tulis di awal karir madrasah dan satu-sunya karya tentang pendidikan. Konsep Pendidikan Ibnu Jama'ah antara lain Konsep Guru/Ulama, Peserta Didik, Materi Pelajaran/Kurikulum dan Metode Pembelajaran serta Lingkungan Pendidikan. Meskipun sangat begitu runtut dan luasnya pembahasan, melalui ilmunya tentang pendidikan ini diharapkan pendidikan era kontemporer dapat mengadopsi dan menerapkannya.
\end{abstract}

Kata Kunci: Ibnu Jama'ah, Konsep Pendidikan, Kontemporer

\section{A. PENDAHULUAN}

Pendidikan merupakan sesuatu yang universal dan berlangsung terus menerus tak terputus dari generasi ke generasi dimanapun di dunia ini. Islam merupakan agama yang mengajarkan konsep pendidikan berdasarkan pada nilai-nilai spiritual yang secara sadar dirancang untuk membantu seseorang atau sekelompok orang dalam mengembangkan pandangan hidup, sikap hidup, 
dan keterampilan hidup, baik yang bersifat manual (petunjuk praktis) maupun mental, dan sosial berdasarkan Al-Qur'an dan Hadits.

Istilah pendidikan secara sederhana dapat diartikan sebagai usaha manusia untuk membina kepribadiannya sesuai dengan nilai-nilai yang terdapat di dalam masyarakat dan bangsa. Dengan demikian, maka pendidikan islam dapat diartikan sebagai usaha manusia untuk membina kepribadiannya sesuai dengan ajaran-ajaran Islam. ${ }^{80}$

Banyak ragam pendapat tentang arti atau makna pendidikan, salah satunya pendidikan didefinisikan sebagai suatu aktivitas dan usaha manusia untuk meningkatkan kepribadiannya dengan jalan membina potensi-potensi pribadinya, yaitu rohani (pikir, cipta, rasa, dan karsa) dan jasmani (Pancaindera serta keterampilan-keterampilan). ${ }^{81}$

Dalam pembahasan pendidikan, islam memberikan kontribusi yang luar biasa melalui pemikiran-pemikiran tokoh dengan hasil berupa konsep pendidikan Islam yang kaya dengan khazanah dan metode yang tepat bagi pendidikan kontemporer. Bahkan jika dibandingkan dengan konsep pendidikan barat, konsep pendidikan dalam islam jauh lebih baik. Konsep pendidikan dari hasil pemikiran tokoh islam tidak hanya berorientasi pada kehidupan duniawi, tapi sekaligus kehidupan ukhrawi. Pendidikan Islam sama sekali tidak berorientasi pada materi, tapi lebih kepada pembentukan manusia yang paripurna, pribadi yang bisa mempertanggungjawabkan hidupnya kepada Sang Pencipta. Tujuan mulia tersebut tidak akan tercapai jika pendidikan

\footnotetext{
${ }^{80}$ Djumransjah, dkk, Pendidikan Islam: Menggali "Tradisi”, Meneguhkan Eksistensi, (Malang: UIN-Malang Press, 2007), hlm 1

${ }^{81}$ Tim Dosen IKIP Malang, Pengantar Dasar-dasar Pendidikan, (Malang: Usaha Nasional, 2003), hlm 7
} 


\section{PEMIKIRAN PENDIDIKAN IBNU JAMA'AH DAN RELEVANSINYA TERHADAP PENDIDIKAN KONTEMPORER}

kontemporer menggunakan konsep barat. Pendidikan islam harus mempraktikkan konsep yang digulirkan oleh ulama-ulama dan praktisi pendidikan Islam melalui karya-karya mereka. Salah satu contohnya Ibnu Jamâ'ah (639-733) dalam Tadzkirah al-Sâmi' wa al-Mutakkalim fi Adab al-'Ilm wa alMuta'allim. Atas dasar tersebut maka dianggap perlu untuk mengkaji lebih mendalam mengenai pemikiran pendidikan Ibnu Jama'ah dan relevansinya terhadap pendidikan kontemporer.

\section{B. PEMBAHASAN}

Badr al-Din Muhammad Ibnu Ibrahim Ibnu Sa'd Allah Ibnu jama'ah Ibnu Ismail Ibnu Jama'ah Ibnu Hazim Ibnu Sakhr Ibnu 'Abd Allah al-Kinani, lahir pada tanggal 4 Rabi' al-Akhir 639/1241, di Hamah, Syria. ${ }^{82}$ Kota kelahiran Ibnu Jama'ah , Hamah, adalah kota penting Syria di samping Damaskus dan Aleppo. Ia relatif berkembang saat kelahiran Ibnu Jama'ah. Pasca invasi Mongol, kota di Syaria memperoleh stabilita dan berkembang. Kota Hamah mengalami kemajuan signifikan pada masa Dinasti Ayyubiyah. Dinasti ini giat membangun institusi ilmiah di kota yang di kuasai, termasuk Hamah. Menjelang kelahiran Ibnu Jama'ah di Hamah terdapat madrasah, khanqah, zawiyah, dan masjid, lengkap dengan dukungan wakaf. Singkatnya, meskipun tidak sebanding Damaskus atau Kairo, Hamah merupakan kota yang hidup, mampu memberi lingkungan ilmiah yang kondusif. ${ }^{83}$

Dalam keluarga dengan empat anak, Ibnu Jama'ah yang terkecil. Keluarga Ibnu Jama'ah mempunyai tradisi intelektual mapan. 'Abd al-Jawwad

\footnotetext{
82 Ibn Jama'ah, Tahqiq Muhammad Ibn Mahdi al-'Ajmi, Tazkirat al-Sami’ wal-Mutakallim,Beirut: Dar alBasyar al-Islami, Beirut: Dar al-Basyar al-Islami, hlm. 3

${ }^{83}$ Hasan Asari, Etika Akademis Dalam Islam, Yogyakarta: Tiara Wacana, 2008, hlm. 27
} 
Khalaf mencatat ada 40 skolar terkenal lahir dari rahim keluarga Ibnu Jama'ah dan hidup sepanjang masa Ayyubiyah dan Mamluk. Beberapa anggota berhasil menjadi faqih, qadli atau khatib terkenal. Fiqh merupakan disiplin utama dalam pendidikan era Mamluk. Menjadi qadli atau khatib merupakan simbol keberhasilan seorang ilmuwan. Beberapa faqih terkenal merupakan berasal dari Bani Jama'ah, mulai kakek dan ayah Ibnu Jama'ah, hingga sepupu dan anakanak mereka. Para faqih dari golongan ini di segani dalam waktu lama di Hamah, Damaskus, Kairo, dan Jerussalem. Ibnu Jamah figur intelektual paling menonjol dari keluarga ini dan meniti karir di kota itu. Namun, ia banyak menghabiskan waktu di kairo. ${ }^{84}$

Sebagai orang yang lahir dari keluarga dengan tradisi ilmiah yang baik, Badr al-Din Ibnu al-Jama'ah (w. 773/1333) mendapat pendidikan terbaik dari zamannya. Ia dibimbing ayahnya sendiri, dan sejumlah ilmuwan terkemuka. Ibnu Jama'ah menempatkan diri sebagai ulama' terkenal periode mamluk yang sukses memadukan karir ilmiah dengan publik. Ia menjadi mudarris di madrasah terbaik di Damaskus, Jerusalem, dan Kairo serta dipercaya sebagai qadi dan qadi al-qudat mazhab Syafi'i. Karirnya mencapai puncak harapan ilmuwan pada era itu. ${ }^{85}$

Sesuai zamannya, Ibnu Jama'ah adalah ilmuwan ensiklopedis, meskipun perhatiannya terfokus pada ilmu agama. Karya beliau mengenai adab atau etika Tazkirah al-Sami' wa al-Mutakallim fi adab al-Alim wa al-Muta'allim, di tulis di awal karir madrasah dan satu-sunya karya tentang pendidikan. Karya ini lanjutan

\footnotetext{
${ }^{84}$ Ibid, hlm. 26

${ }^{85}$ Ibid, hlm. 111
} 


\section{PEMIKIRAN PENDIDIKAN IBNU JAMA'AH DAN RELEVANSINYA TERHADAP PENDIDIKAN KONTEMPORER}

karya sejenis yang ditulis ilmuwan sebelumnya. Cenderung sama, sekaligus refleksi kemunduran pendidikan abad pertengahan islam. Empat tema menjadi fokus pemikiran Ibnu Jama'ah dalam buku ini: etika ilmuwan, etika murid, etika terhadap buku, dan etika penghuni madrasah. Ibnu Jama'ah memulai pendidikannya pada usia sangat dini. Ini tidak terlalu aneh karena ia lahir dalam keluarga dengan tradisi ilmiah yang baik. Lagi pula belajar pada usia tujuh tahun tidak bertentangan dengan praktik pendidikan pada abad pertengahan. Meskipun terdapat variasi usia pada pendidikan formal. Ibnu Hazm (w.456/1064) berpendapat, pendidikan dasar formal (kuttab) sebaiknya dimulai sejak usia lima tahun. Ibnu al-Jawzi (w 597/1200) melaporkan, ia masuk kuttab pada usia enam tahun. Namun, banyak teman kelasnya berusia lebih tua. ${ }^{86}$ Pendidikan Ibnu Jama'ah mengikuti jalur yang lazim ditempuh orang pada umumnya. Dari guru dan mobilitasnya mencari pengetahuan, ia memperoleh pendidikan terbaik. Ibnu Jama'ah diberkahi latas belakang yang kondusif. Maka ia tumbuh menjadi intelektual muda sukses. Karir Ibnu Jama'ah bisa digambarkan perpaduan antara mengajar dan qadi yang dijalani dalam satu iklim sosio politik yang sangat dinamis. Ibnu Jama'ah mendapat pengajaran agama dari beberapa guru yang sangat terkenal di tempat dan masanya, baik oleh ayahnya sendiri maupun guru lain, diantaranya: Shofi al-Din Ibnu alBaradzi'i wafat 647 H, al-Rasyid Ibnu Maslamah. w. 650H., al-Rasyid al-Iraqi. w. 652 H, Syaih al-Syuyuh al-Anshari. w. $662 \mathrm{H}$, al-Rasyid al-'Aththar. w. $662 \mathrm{H.}$, al-Radli Ibnu al-Burhan. w. 664 H, Ibnu 'Abd al-Warits. w. 665 H, Ibnu al-Qasthalani. w.

\footnotetext{
86 'Abd al-Jawwad Khalaf, al-Qadi Badr al-Din Ibnu Jama'ah Hayatuhu wa Asaruhu, Karachi: Jami'ah alDirasah al-Islamiyah, 1988, hlm. 7
} 
665 H, Ibnu 'Izwan. w. 667 H, al-Majdu Ibnu Daqiq. w. 667 H, Ibnu 'Abd al-Daim. w. $668 \mathrm{H}$, Syaraf al-Din al-Sabaqi. w. $669 \mathrm{H}$, al-Muin al-Dimasyqa. w. $670 \mathrm{H}, \mathrm{Ibnu}$ Malik. w. 672 H, al-Kamal Ibnu 'Abd. w. 672 H, Ibnu Abi al-Yasar. w. 672 H, Ibnu Alaq. w. 672 H, al-Najib. w. 672 H, Ibnu 'Atha' al-Hanaf i. w. 673 H, Ibrahim Ibnu Jama'ah. w. 675 H, Ibnu Razin. w. 680 H, Ibnu 'Alan.w. 680 H, Ibnu 'Abi 'Amr. w. $682 \mathrm{H}$, Ibnu al-Mutawwij. w. $730 \mathrm{H}^{87}$

Sedangkan murid-murid Ibnu Jama'ah Sangat banyak sekali, dan tersebar di pelosok Jazirah Arab Diantara muri-murid beliau yang sangat terkenal antara lain: al-Imam Atsir al-Din Abu Hayyan, al-'Allamah Taju al-Din al-Sabaki, alMuarrikh al-Kabir Shalah al-Din al-Shafadi, al-Imam al-Muhaddits Nur al-Din 'Ali Ibnu Jabir al-Hasyimi, al-Faqih al-Kabir Qutb al-Din al-Sanbathi, Syihab al-Din alHakari, al-Imam al-Kabir Syams al-Din Ibn al-Qamakh, Muhammad Ibnu Muhammad Ibn al-Husaini al-Halabi, al-Syaikh al-Qadli 'Imad al-Din al-Balbisi. ${ }^{88}$

Sebagai ilmuwan, bahwa Ibnu Jama'ah punya karya beragam. Biografi dan komentar tentangnya menunjuk demikian. Banyak karya beliau belum dipublikasikan. Sebagian belum diketahui apakah masih utuh dan berhasil diwariskan. ${ }^{89}$ Berikut diberikan daftar karya Ibnu Jama'ah yang didapat dari catatan biografi ilmuwan muslim. Karya-karya ini disebut secara berserakan di berbagai sumber. Diantara karya beliau adalah :

\footnotetext{
${ }^{87}$ Ibid, hlm. 47

${ }^{88}$ Ibid, hlm. 62

${ }^{89}$ Haji Khalifah, Kasyf al-Zunun 'an Asami al-Kutub wal-Funun, Istanbul: Wakalah al-Ma'arif, 1941-1943, hlm.720
} 


\section{PEMIKIRAN PENDIDIKAN IBNU JAMA'AH DAN RELEVANSINYA TERHADAP PENDIDIKAN KONTEMPORER}

1. Ulum al-Qur'an: al-Tibyan fi Mubhamat al-Qur'an, Ghurar al-Tibyan fi man lam Yusammi fi al-Qur'an, al-Fawaid al-Laihah min Surah al-Fatihah, Kasyf al-Ma'ani an al-Mutasyabih min al-Matsani, al-Muqtas fi Fawaid Takrir al-Qishash

2. Ulum al-Hadits: al-Manhal al-Rawi fi Mukhtashar 'Ulum al-Hadits al-Nabawi, alFawaid al-Gazirah al-Mustanbat min Hadits Barirah, Muhtashar fi Munasabat Tarajum al-Bukhari li Ahadits al-Abwab, Mukhtasar Afsa al-Amal wal-Syawq fi 'Ulum Hadits al-Rasul li-Ibnu al-Shalah, 'Arba'un Haditsan Tusa'iyan

3. Fiqh: al-'Umdah fi al-Ahkam, Kasyf al-Ghummah fi Ahkam Ahl al-Zimmah, alTha'ah fi Fadlilati Shalat al-Jama'ah, al-Masalik fi Ilm al-Masalik, Tanqih alMunazzarat fi tashih al-Mukhabarah

4. Kalam: al-Radd 'ala al-Musyabbahah fi Qawlihi Ta'ala "al-Rahman 'Ala al-'Arsy Istawa", al-Tanzih fi Ibtal Hujjah al-Tasybih, Idlah al-Dalil fi Qath'i Hujaj al-Ta'til 5. Sejarah: al-Mukhtashar al-Kabir fi al-Sirah, Nur al-Rawd

6. Nahwu: Syarh Kafiyah Ibnu al-Hajib, al-Dliya' al-Kamil wa Syarh al-Syamil 7. Sastra: Lisan al-'Adab, Diwan al-Kitab, Arjuzah fi al-Khulafa', Arjuzah fi Qadlati alSyam

8. Perang: Tajnid al-Ajnad wa-Jihat al-Jihad, Mustanid al-Ajnad fi Alat al-Jihad, Awtsaq al-Asbab

9. Astrologi: Risalah fi al-Astaralib

10. Pendidikan: Tazkirah al-Sami' wa al-Mutakallim fi 'Adab al-'Alim wal-Muta'allim 11. Politik: Tahrir al-Ahkamfi Tadbir Ahl al-Islam, Hujjat al-Suluk fi Muhadat alMuluk.90

\footnotetext{
${ }^{90}$ Abd al-Jawwad Khalaf, al-Qadi Badr al-Din Ibnu Jama'ah, hlm. 68-75
} 
Konsep pendidikan yang dikemukakan Ibnu Jama'ah secara keseluruhan dituangkan dalam karyanya Tadzkirat as-Sami' wa al-Mutakallim fi Adab al-Alim wa al-Muta'allim. Dalam buku tersebut beliau mengemukakan tentang keutamaan ilmu pengetahuan dan orang yang mencarinya. Keseluruhan konsep pendidikan Ibnu Jama'ah ini dapat dikamukakan sebagai berikut :

1. Konsep Guru/Ulama

Menurut Ibnu Jama'ah bahwa ulama sebagai mikrokosmos manusia dan secara umum dapat dijadikan sebagai tipologi makhluk terbaik (khair albariyah). Atas dasar ini, maka derajat seorang alim berada setingkat dibawah derajat Nabi. Hal ini didasarkan pada alasan karena para ulama adalah orang yang paling takwa dan takut kepada Allah SWT. Dari konsep tentang seorang alim tersebut, Ibnu Jama'ah membawa konsep tentang guru. Untuk itu Ibnu Jama'ah menawarkan sejumlah kriteria yang harus dipenuhi oleh seseorang yang ingin menjadi seorang guru. Kriteria pendidik tersebut meliputi 6 hal. Pertama, menjaga akhlak selama melaksanakan tugas pendidikan. Kedua, tidak menjadikan profesi guru sebagai usaha untuk menutupi kebutuhan ekonominya. Ketiga, mengetahui situasi social kemasyarakatan. Keempat, kasih saying dan sabar. Kelima, adil dalam memperlakukan peserta didik. Keenam, menolong dengan kemampuan yang dimilikinya. Dari keenam kriteria tersebut, yang menarik adalah kriteria tentang tidak bolehnya profesi guru dijadikan sebagai usaha mendapatkan keuntungan materil, suatu konsep yang di masa sekarang tampak kurang relevan, karena salah satu ciri kerja professional adalah pekerjaan dimana 


\section{PEMIKIRAN PENDIDIKAN IBNU JAMA'AH DAN RELEVANSINYA TERHADAP PENDIDIKAN KONTEMPORER}

orang yang melakukannya menggantungkan kehidupan di atas profesinya itu. Namun Ibnu Jama'ah berpendapat demikian sebagai konsekuensi logis dari konsepnya tentang pengetahuan. Bagi Ibnu Jama'ah pengetahuan (ilmu) sangat agung lagi luhur, bahkan bagi pendidik menjadi kewajiban tersendiri untuk mengagungkan pengetahuan tersebut, sehingga pendidik tidak menjadikan pengetahuannya itu sebagai lahan komoditasnya, dan jika hal itu dilakukan berarti telah merendahkan keagungan pengetahuan. Secara umum kriteria-kriteria tersebut diatas menampakkan kesempurnaan sifat-sifat dan keadaan pendidik dengan memiliki persyaratan-persyaratan tertentu sehingga layak menjadi pendidik sebagaimana mestinya.

Dari beberapa kriteria tersebut sangat dimungkinkan untuk diterapkan dalam pendidikan kontemporer yang menunjukkan peran penting guru sebagai contoh bagi siswa tidak hanya di dalam melainkan juga di luar kelas. Kemudian adanya penekanan untuk knowledge oriented sebagaimana pendidikan pada masa kejayaan islam, hal ini yang semakin bergeser pada masa modern yang lebih mengutamakan certificate oriented. Guru juga dihadapkan pada peran dalam masyarakat yang mengharuskannya memahami keadaan sekitar agar dengan kemampuan yang dimilikinya, guru dapat mengubah keadaan menjadi lebih baik.

2. Peserta Didik

Menurut Ibnu Jama'ah peserta yang baik adalah peserta didik yang mempunyai kemampuan dan kecerdasan untuk memilih, memutuskan dan mengusahakan tindakan-tindakan belajar secara mandiri, baik yang 
berkaitan dengan aspek fisik, pikiran, sikap maupun perbuatan. Dengan demikian dapat dipastikan bahwa peserta didik telah melewati masa kanakkanak yang dalam tradisi pendidikan islam biasanya belajar di kuttab. Ibnu jama'ah sangat mendorong para siswa agar mengembangkan kemampuan akalnya. Menurut Ibnu Jama'ah bahwa akal merupakan anugerah dari Tuhan yang sangat istimewa dan berharga, dan oleh karenanya patut disyukuri dengan jalan memanfaatkannya secra optimal. Atas dasar ini, maka Ibnu Jama'ah menganjurkan agar setiap peserta didik mengembangkan daya inteleknya guna menemukan kebenaran-kebenaran yang ada dalam kajian apapun, termasuk dalam kajian keimanan atau ibadah. Dengan menggunakan akal tersebut, setiap siswa akan menemukan hikmah dari setiap bidang kajian ilmu yang dipelajarinya. Sejalan dengan pemikiran tersebut diatas, Ibnu Jama'ah telah memberikan petunjuk dan doringan yang sangat jelas bagi peserta didik, yaitu agar tekun dan benarbenar giat dalam mengasah kecerdasan akalnya, serta menyediakan waktuwaktu tertentu untuk mengembangkan daya intelek tersebut.

Dewasa ini pendidikan kontemporer memberikan istilah kognitif, afektif, dan psikomotor dalam hal penilaian terhadap kemampuan anak. Hal ini sesuai dengan konsep Ibnu Jama'ah yang memandang penting mengusahakan tindakan-tindakan belajar secara mandiri, baik yang berkaitan dengan aspek fisik, pikiran, sikap maupun perbuatan tanpa mengesampingkan ibadah.

3. Materi Pelajaran/Kurikulum 


\section{PEMIKIRAN PENDIDIKAN IBNU JAMA'AH DAN RELEVANSINYA TERHADAP PENDIDIKAN KONTEMPORER}

Materi pelajaran yang dikemukakan Ibnu Jama'ah terkait dengan tujuan belajar, yaitu semata-mata menyerahkan diri sepenuhnya kepada Allah SWT, dan tidak untuk kepentingan mencari dunia atau materi. Sejalan dengan tujuan tersebut diatas, maka materi pelajaran yang diajarkan harus dikaitkan dengan etika dan nilai-nilai spiritualitas. Dengan demikian, ruang lingkup epistimologi persoalan yang dikaji oleh pesrta didik menjadi meluas, yaitu meliputi epistimologi kajian keagamaan dan epistimologi diluar wilayah keagamaan (sekuler). Namun demikian wilayah kajian sekuler tersebut harus senantiasa mengacu kepada tata nilai religi. Namum demikian, Ibnu Jama'ah lebih menitikberatkan pada kajian materi keagamaan. Hal ini antara lain terlihat pada pandangannya mengenai urutan matrei yang dikaji sangat menampakkan materi-materi keagamaan. Urutan mata pelajaran yang dikemukakan Ibnu Jama'ah adalah pelajaran Al-quran, tafsir, hadits, ulum al-hadits, ushul al-fiqh, nahwu dan shorof. Setelah itu dilanjutkan dengan pengembangan-pengembangan bidang lain dengan tetap mengacu kepada kurikulum diatas. Menurut Ibnu jama'ah, bahwa kurikulum yang penting dan mulia haruslah didahulukan dengan kurikulum lainnya. Ini artinya bahwa peserta didik dapat melakukan kajian terhadap kurikulum diatas secara sistematik. ${ }^{91}$ Ibnu Jama'ah memprioritaskan kurikulum Al-Qur'an daripada yang lainya. Mengedepankan kurikulum ini agaknya tepat. Karena sebagaimana pendapat Muhammad Faisal Ali Sa'ud, kurikulum Al-Qur'an merupakan ciri yang membedakan antara kurikulum pendidikan Islam dengan

\footnotetext{
${ }^{91}$ Abuddin Nata, Pemikiran Para Tokoh Pendidikan Islam, Jakarta (Raja Grafindo Persada, 2001) hlm. 115-120
} 
pendidikan lainya. Sudah seharusnya kurikulum pendidikan Islam disusun sesuai dengan Al-Qur'an Al-Karim, dan ditambah dengan Al-Hadits untuk melengkapinya. ${ }^{92}$

Dalam hal kurikulum, Ibnu Jama'ah memberikan spesifikasi secara runtut untuk mempelajari ilmu secara berurutan mulai dari yang terpenting yaitu Al-quran, tafsir, hadits, ulum al-hadits, ushul al-fiqh. Sehingga agama sangat diprioritaskan karena menjadi pembeda terhadap ilmu yang lain. Hal ini yang perlu dijadikan pedoman oleh pendidikan kontemporer yang semakin mensejajarkan ilmu agama dengan ilmu yang lain sehingga terjadi ketidakseimbangan yang mengakibatkan ilmu agama semakin terpinggirkan.

4. Metode Pembelajaran Konsep Ibnu Jama'ah tentang metode pembelajaran banyak ditekankan pada hafalan ketimbang dengan metode lain. Metode hafalan memang kurang memberikan kesempatan pada akal untuk mendayagunakan secara maksimal proses berfikir, akan tetapi, hafalan sesungguhnya menantang kemampuan akal untuk selalu aktif dan konsentrasi dengan pengetahuan yang didapat. Selain metode ini, beliau juga menekankan tentang pentingnya menciptakan kondisi yang mendorong kreativitas para siswa, menurut beliau kegiatan belajar tidak digantungkan sepenuhnya kepada pendidik, untuk itu perlu diciptakan peluang-peluang yang memungkinkan dapat mengembangkan daya kreasi dan daya intelek peserta didik.

${ }^{92}$ Ramayulis, Ilmu Pendidikan Islam, Jakarta (Kalam Mulia, 1994) hlm.65 


\section{PEMIKIRAN PENDIDIKAN IBNU JAMA'AH DAN RELEVANSINYA TERHADAP PENDIDIKAN KONTEMPORER}

Metode pembelajaran kontemporer yang sedang berkembang mungkin menganggap hafalan sebagai salah satu metode tradisional dalam pembelajaran, sehingga semakin ditinggalkan karena dianggap monoton dan membosankan. Namun dalam mata pelajaran tertentu, metode hafalan masih diperlukan setidaknya untuk memberikan kesempatan pada anak untuk menghafalkan hal-hal positif dibandingkan dengan menghafal hal-hal yang tidak dibutuhkan.

5. Lingkungan Pendidikan

Para ahli pendidikan sosial umumnya berpendapat bahwa perbaikan lingkungan merupakan syarat mutlak untuk mewujudkan tujuan-tujuan pendidikan. Sejalan dengan hal diatas Ibnu Jama'ah memberikan perhatian yang besar terhadap lingkungan. Menurutnya bahwa lingkungan yang baik adalah lingkungan yang didalamnya mengandung pergaulan yang menjunjung tinggi nilai-nilai etis. Pergaulan yang ada bukanlah pergaulan bebas, tetapi pergaulan yang ada batas-batasnya. Lingkungan memiliki peranan dalam pembentukan keberhasilan pendidikan. Keduanya menginginkan adanya lingkungan yang kondusif untuk kegiatan belajar mengajar, yaitu kondisi lingkungan yang mencerminkan nuansa etis dan agamis. ${ }^{93}$

Dalam hal lingkungan pendidikan, Ibnu Jama'ah memprioritaskan perhatiannya pada lingkungan pembelajaran yang menjunjung tinggi nilai etis dan kondusif. Hal ini juga diusung oleh pendidikan kontemporer untuk menciptakan suasana belajar yang nyaman dan menyenangkan tidak hanya

${ }^{93}$ http://em-aziez.blogspot.com/2007/12/ibnu-jamaah.html 
didukung oleh fasilitas yang memadai namun juga oleh pergaulan yang mendukung perkembangan positif pada anak.

Selain itu dibahas etika akademis yang dibagi kedalam: 1) etika ilmuwan ('alim); 2) etika penuntut ilmu (muta'allim); 3) etika terhadap buku; dan 4) etika para penghuni asrama. ${ }^{94}$ Ibnu Jama'ah dalam hal ini, menempatkan dua belas poin etika yang menjadi kepribadian ilmuwan yang baik, diantaranya : Pertama, ilmuwan senantiasa dekat dengan Allah SWT, sendirian maupun bersama orang lain. Kedua, ilmuwan harus memelihara ilmu pengetahuan sebagaimana para ulama' salaf memeliharanya. Ketiga, ilmuwan harus zuhud dan menghindari kekayaan material berlebihan. Keempat, Ilmuwan tidak menjadikan ilmu sebagai alat mencapai tujuan duniawi seperti kemuliaan, kekayaan, ketenaran, atau bersaing dengan orang lain. Kelima, ilmuwan harus terhindar dari tindakan tercela atau kurang pantas, baik agama maupun adat. Keenam, ilmuwan melaksanakan ajaran agama dan mendukung syi'ar. Ketujuh, lmuwan dapat memelihara amalan sunat, baik berupa perbuatan maupun perkataan. Kedelapan, ilmuwan memperlakukan masyarakat dengan dengan akhlak mulia. Kesembilan, ilmuwan membersihkan diri dari akhlak buruk dan menumbuhkan ahlak terpuji. Kesepuluh, ilmuwan memperdalam ilmu pengetahuan terus menerus. Kesebelas, ilmuwan tidak boleh segan belajar dari yang lebih rendah jabatan, keturunan, atau usia. Keduabelas, ilmuwan mentradisikan menulis dalam bidang yang ditekuni dan dikuasai. ${ }^{95}$

\footnotetext{
${ }^{94}$ Hasan Asari, Etika Akademis Dalam Islam, hlm. 41

${ }^{95}$ Ibn Jama'ah, Tahqiq Muhammad Ibn Mahdi al-'Ajmi, Tazkirat al-Sami’, hlm. 44-55
} 


\section{PEMIKIRAN PENDIDIKAN IBNU JAMA'AH DAN RELEVANSINYA TERHADAP PENDIDIKAN KONTEMPORER}

Kemudian dalam etika mengajar, Ibn Jama'ah dalam hal ini juga menempatkan dua belas poin tentang etika yang berkaitan dengan mengajar, diantaranya : Pertama, menjelang mengajar, ilmuwan membersihkan diri dari hadats dan kotoran, merapikan diri, serta mengenakan pakaian bagus. Kedua, keluar dari rumah, seorang ilmuwan hendaknya berdo'a mencari ilmu (thalab al-Ilm), mengingat Allah SWT, mengucap salam kepada yang hadir, lalu melaksanakan shalat dua raka'at (khususnya majlis di masjid). Ketiga, duduk pada posisi yang bisa dilihat seluruh yang hadir. Keempat, membaca ayat alQur'an sebelum pelajaran dimulai agar berkah, mendo'akan diri sendiri, hadirin, dan kaum muslimin. Kelima, jika mengajarkan beberapa disiplin ilmu dalam sehari, maka harus mendahulukan yang lebih mulia dan lebih penting. Keenam, mengatur suara agar tidak terlalu lemah hingga sulit didengar hadirin, juga tidak terlalu keras hingga mengganggu orang di luar majelis. Ketujuh, menjaga majelis agar tidak menjadi ajang senda gurau, kebisingan, atau perdebatan yang tidak jelas yang hanya mengakibatkan kelupaan. Kedelapan, mengingatkan orang yang berlebihan dalam debat, atau bingung dalam debat, atau jelek tata krama, atau tak mau tenang setelah ditemukan kebenaran. Kesembilan, ilmuwan harus bersikap adil dalam memberikan pelajaran. Kesepuluh, memberi penghargaan sewajarnya terhadap orang asing (bukan anggota kelas reguler) yang datang ketika majlis sedang berlangsung, dengan mempersilahkan dan menerimanya dengan baik. Kesebelas, mengakhiri pelajaran dengan Wallahu A'lam seperti halnya mufti mengakhiri jawaban tertulis. 
Keduabelas, ilmuwan harus mengetahui keahlian dan mengajarkan bidang keahlian itu. ${ }^{96}$

Dalam etika murid, Ibnu Jama'ah mengklasifikasi menjadi sepuluh etika yang merupakan dasar kesiapan menjadi penuntut ilmu yang baik, diantaranya : Pertama, membersihkan hati dari kotoran, sifat buruk, aqidah keliru, dan aqidah tercela. Kedua, meluruskan niat hanya karena Allah SWT, menghidupkan syariat islam, menyinari hati dan mengasah bathin dalam rangka mendekatkan diri pada Allah SWT. Ketiga, menghargai waktu dengan mencurahkan perhatian untuk urusan menuntut ilmu pengetahuan. Keempat, menjaga kesederhanaan pakaian dan makanan. Kelima, membuat jadwal kegiatan yang ketat dan jelas manfaatnya. Keenam, menghindari makan terlalu banyak. Ketujuh, bersifat wara' papan, sandang, pangan semua diperoleh dengan cara yang halal. Kedelapan, mengurangi konsumsi makanan yang bisa menyebabkan kebodohan dan lemahnya indera seperti apel asam, kubis atau cuka. Kesembilan, meminimalkan waktu tidur, tetapi tidak menggangu kesehatan. Kesepuluh, membatasi pergaulan hanya dengan orang yang bisa bermanfaat bagi belajar. ${ }^{97}$

Ibnu Jama'ah juga memberikan penjelasan tentang etika terhadap buku. Selain karya Ibn Jama'ah, etika terhadap buku juga dijumpai dalam karya al'Almawi, al-Mu'id fi Adab al-Mufid wal-Mustafid, yang dikutib di depan. Adapun etika terhadap buku menurut Ibn Jama'ah antara lain : Pertama, murid senantiasa berupaya memperoleh buku yang dibuuhkan dengan jalan membeli, menyewa, atau meminjam. Kedua, seseorang hanya meminjamkan buku kepada

\footnotetext{
${ }^{96}$ Hasan Asari, Etika Akademis Dalam Islam, hlm. 51

${ }^{97}$ Ibn Jama'ah, Tahqiq Muhammad Ibn Mahdi al-'Ajmi, Tazkirat al-Sami’, hlm. 80-88
} 


\section{PEMIKIRAN PENDIDIKAN IBNU JAMA'AH DAN RELEVANSINYA TERHADAP PENDIDIKAN KONTEMPORER}

orang yang diyakini memanfaatkan buku tanpa merusak. Ketiga, waktu membaca, buku tidak dibiarkan terletak di lantai dan terlempar secara berlebihan. Keempat, jika meminjam buku, seseoarng harus memeriksa saat mengambil dan saat mengembalikan. Kelima, saat menyalin buku ilmu agama, seseorang harus suci, bersih badan dan pakaian, menghadap qiblat, serta memulai naskah dengan membaca basmalah. Keenam, dalam menyalin hendaknya dihindari tulisan yang terlalu halus, karena bisa mengakibatkan kurang jelasnya tulisan. Ketujuh, jika naskah buku dibandingkan dengan naskah lain yang benar atau dengan bantuan syaikh, maka harus diberi tanda harakat dan diakritik. Bagian yang potensial menimbulkan salah ejaan dan membutuhkan perbaikan harus diperhatikan khusus. Kedelapan, jika ingian membuat penjelasan (takhrij, terkadang disebut juga al-Lahq) tentang sesuatu dari matan, ia dapat membuatnya di margin buku. Kesembilan, boleh menulis judul bab, nama-nama tokoh, dan pasal-pasal buku dengan tinta merah, atau tulisan tebal, untuk mempermudah dalam mencari kalimat. Kesepuluh, dalam koreksi tambahan atau kekeliruan naskah, cara membuang atau menghapus (alDarb) lebih baik daripada menggosok kertas (al-Hakk) hingga tulisan hilang. Kesebelas, pemilik buku boleh membuat hasyiyah, faidah atau tanbih pada margin buku. ${ }^{98}$

Tradisi menyediakan tempat tinggal bagi murid di madrasah-madrasah dilatarbelakangi dua fenomena, pertama, formalisasi pendidikan, dengan tumbuhnya institusi pendidikan; kedua, munculnya kesediaan menyediakan waqaf sebagai pendanaan kegiatan pendidikan. Dalam hal penyediaan

\footnotetext{
${ }^{98}$ Ibn Jama'ah, Tahqiq Muhammad Ibn Mahdi al-‘Ajmi, Tazkirat al-Sami’, hlm. 116-124
} 
penghuni madrasah Ibnu Jama'ah mempunyai sebelas etika yang harus diterapkan untuk menjaga keharmonisan penghuni madrasah, diantaranya : Pertama, murid yang ingin tinggal di asrama harus memastikan bahwa madrasah dan waqaf berasal dari harta halal, dan pemberi waqah adalah wara'. Kedua, mudarris (dosen) yang mengajar madrasah harus ilmuwan yang mendekati kriteria etika ilmuwan baik; pakar dibidangnya, religius, cerdas serta berwibawa. Ketiga, penghuni madrasah harus berupaya semaksimal mungkin untuk selalu mentaati pelaturan yang berlaku dan dicantumkan dalam waqfiyyah madrasah. Keempat, jika pemberi waqaf mensyaratkan yang berhak menghuni asrama adalah orang-orang yang dapat beasiswa saja, maka seorang yang di luar itu tidak berhak tinggal. Kelima, seseoarng yang tinggal di madrasah harus benar-benar konsentrasi pada menuntut ilmu. Keenam, penghuni asrama harus saling menghormati, memberi salam, saling membantu dan saling memaafkan. Ketujuh, sedapat mungkin penghuni asrama memilih kamar dengan bertetangga dengan yang saleh, rajin, dan berperilaku baik. Kedelapan, jika tinggal dekat dengan masjid atau perkumpulan lain yang menggunakan karpet atau tikar, harus menjaga kebersiahn dari kotoran sandal yang jatuh. Kesembilan, penghuni asrama dilarang duduk-duduk di pintu, kecuali terpaksa, tidak di koridor menuju jalan. Kesepuluh, tidak diperbolehkan melihat dari celah pintu kamar orng lain meski lewat di depannya. Kesebelas, mengupayakan agar selalu tiba di majelis lebih dulu dari guru. Ulama' salaf mengatakan:"Salah satu etika terhadap mudarris adalah bahwa para murid menunggunya, bukan sebaliknya, guru menunggu murid." 99

${ }^{99}$ Ibn Jama'ah, Tahqiq Muhammad Ibn Mahdi al- 'Ajmi, Tazkirat al-Sami’, hlm. 125-133 


\section{PEMIKIRAN PENDIDIKAN IBNU JAMA'AH DAN RELEVANSINYA}

TERHADAP PENDIDIKAN KONTEMPORER

\section{Kesimpulan}

Pada masa Ibnu Jama'ah telah muncul berbagai lembaga pendidikan diantaranya adalah kuttab, pendidikan istana, kedai atau toko kitab, rumah para ulama, rumah sakit, perpustakaan, dan masjid. Konsep ilmu yang dipaparkan Ibnu Jama'ah dalam kitab Tazkirat al-Sami' wal-Mutakallim, sangat begitu runtut dan luasnya pembahasan, melalui ilmunya tentang pendidikan ini diharapkan pendidikan era kontemporer dapat mengadopsi dan menerapkannya. Mulai dari konsep ilmu, hakekat ilmu, keagungan dan kemuliaan ilmu, manfaat bagi yang mempelajari dan mengajarkan ilmu, etika ilmuwan, etika yang pencari ilmu, etika mengajar, etika mudarris, etika terhadap guru dan murid, etika terhadap buku, etika penghuni asrama. Adapun Konsep Pendidikan Ibnu Jama'ah antara lain :

1. Konsep Guru/Ulama. Ibnu Jama'ah menawarkan sejumlah kriteria yang harus dipenuhi oleh seseorang yang ingin menjadi seorang guru. Kriteria pendidik tersebut meliputi 6 hal. Pertama, menjaga akhlak selama melaksanakan tugas pendidikan. Kedua, tidak menjadikan profesi guru sebagai usaha untuk menutupi kebutuhan ekonominya. Ketiga, mengetahui situasi social kemasyarakatan. Keempat, kasih sayang dan sabar. Kelima, adil dalam memperlakukan peserta didik. Keenam, menolong dengan kemampuan yang dimilikinya.

2. Peserta Didik. Menurut Ibnu Jama'ah peserta yang baik adalah peserta didik yang mempunyai kemampuan dan kecerdasan untuk memilih, memutuskan dan mengusahakan tindakan-tindakan belajar secara mandiri, baik yang berkaitan dengan aspek fisik, pikiran, sikap maupun perbuatan. 
3. Materi Pelajaran/Kurikulum. Ibnu Jama'ah memprioritaskan kurikulum AlQur'an daripada yang lainya. Kurikulum Al-Qur'an merupakan ciri yang membedakan antara kurikulum pendidikan Islam dengan pendidikan lainya. Sehingga seharusnya kurikulum pendidikan Islam disusun sesuai dengan Al-Qur'an Al-Karim, dan ditambah dengan Al-Hadits untuk melengkapinya.

4. Metode Pembelajaran. Konsep Ibnu Jama'ah tentang metode pembelajaran banyak ditekankan pada hafalan ketimbang dengan metode lain, karena sesungguhnya hafalan menantang kemampuan akal untuk selalu aktif dan konsentrasi. Selain metode ini, beliau juga menekankan tentang pentingnya menciptakan kondisi yang mendorong kreativitas para siswa.

5. Lingkungan Pendidikan. Menurut Ibnu Jama'ah bahwa lingkungan yang baik adalah lingkungan yang didalamnya mengandung pergaulan yang menjunjung tinggi nilai-nilai etis.

Peran penting guru dalam pendidikan tradisional maupun kontemporer sebagai contoh bagi siswa diharapkan untuk menjunjung tinggi knowledge oriented dari pada certificate oriented. Pendidikan kontemporer memberikan istilah kognitif, afektif, dan psikomotor dalam hal penilaian terhadap kemampuan anak sesuai konsep Ibnu Jama'ah yang memandang penting mengusahakan tindakan-tindakan belajar secara mandiri, baik yang berkaitan dengan aspek fisik, pikiran, sikap maupun perbuatan tanpa mengesampingkan aspek keimanan.

Agama dalam kurikulum patut diprioritaskan karena menjadi pembeda terhadap ilmu lain. Hal ini perlu dijadikan pedoman oleh pendidikan 


\section{PEMIKIRAN PENDIDIKAN IBNU JAMA'AH DAN RELEVANSINYA TERHADAP PENDIDIKAN KONTEMPORER}

kontemporer yang semakin mensejajarkan ilmu agama dengan ilmu yang lain sehingga terjadi ketidakseimbangan. Selain itu kualitas pendidikan didukung oleh lingkungan pembelajaran yang menjunjung tinggi nilai etis dan kondusif. Pendidikan kontemporer dengan perkembangannya masih membutuhkan konsep pendidikan hasil pemikiran ulama' terdahulu sebagai tolak ukur kualitas pendidikan pada masanya.

\section{Daftar Pustaka}

Djumransjah, dkk, Pendidikan Islam: Menggali "Tradisi", Meneguhkan Eksistensi, (Malang: UIN-Malang Press, 2007)

Tim Dosen IKIP Malang, Pengantar Dasar-dasar Pendidikan, (Malang: Usaha Nasional, 2003)

Ibn Jama'ah, Tahqiq Muhammad Ibn Mahdi al-'Ajmi, Tazkirat al-Sami' walMutakallim,Beirut: Dar al-Basyar al-Islami, Beirut: Dar al-Basyar al-Islami Hasan Asari, Etika Akademis Dalam Islam, Yogyakarta: Tiara Wacana, 2008

Haji Khalifah, Kasyf al-Zunun 'an Asami al-Kutub wal-Funun, Istanbul: Wakalah al-Ma'arif, 1941-1943

Abd al-Jawwad Khalaf, al-Qadi Badr al-Din Ibnu Jama'ah Hayatuhu wa Asaruhu, Karachi: Jami'ah al-Dirasah al-Islamiyah, 1988

Abuddin Nata, Pemikiran Para Tokoh Pendidikan Islam, Jakarta (Raja Grafindo Persada, 2001)

Ramayulis, Ilmu Pendidikan Islam, Jakarta (Kalam Mulia, 1994) http:/ / em-aziez.blogspot.com/2007/12/ibnu-jamaah.html 
Muhamad Khoirur Roziqin dan Ella Nurmawati 